\title{
Research on the Carbon Dioxide Emission Factor as a Result of Fuel Combustion
}

\begin{abstract}
TUDORA CRISTESCU*, MONICA EMANUELA STOICA, SILVIAN SUDITU
Petroleum - Gas University of Ploiesti, Drilling, Extraction and Transport of Hydrocarbons Department, 39 Bucuresti Blvd., 100680, Ploiesti, Romania

The present paper first discusses a calculation model for the complete combustion of fuels - with the minimum amount of air needed - whose volumetric and mass composition is known. It then describes evaluation models for the heat resulting from fuel combustion, i.e., superior and inferior caloric power value. In this context, the carbon dioxide emission factors for fuel and biofuel combustion, respectively, are evaluated. The results obtained have allowed a comparative analysis regarding carbon dioxide emission.
\end{abstract}

Keywords: complete fuel combustion, biofuels, carbon dioxide emission factor

The meteorological phenomena we have been facing lately are the direct or indirect result of human activity. They are the consequences of climate change. Ensuring energy security with competitive and clean energy, taking into account the limitation of climate change, represents a major challenge for the European Union.

The vision of the current European energy policy is in line with the concept of sustainable development and it refers, among others, to the reduction of greenhouse gas (GHG) emissions [1]. Nationally, policies and action plans to reduce GHG emissions are a key element in limiting the effects of climate change on the environment, the economy and society. They are in line with the European requirements regarding this domain. In this respect, the National Strategy on Climate Change of Romania 20132020, adopted in July 2013, and the National Strategy on Climate Change and Economic Growth regarding low carbon emissions have been published, identifying the main sectors for priority actions for reducing GHG emissions, such as energy, transport, industrial processes, agriculture and rural development, urban development, waste management, water and forestry [2].

In 2016, compared to 2015, Romania recorded a $1.4 \%$ drop in $\mathrm{CO}_{2}$ emissions from fossil fuel combustion. Carbon dioxide emissions in the EU dropped by $0.4 \%$ overall. In 2016, the share of $\mathrm{CO}_{\text {e emissions in Romania accounted }}$ for $2.1 \%$ of total EU CO emissions [3].

Periodic statistical surveys on the production of electricity and heat, resources and electric power consumption, heat, fuels, fuels and lubricants, the monitoring of carbon dioxide emissions, have led to their classification according to various criteria [4-8].

Reducing greenhouse gas emissions and, consequently, preventing dangerous climate change can be achieved by reducing energy consumption and by using secondary energy sources and renewable energy sources, respectively [9].

Fuels are substances that burn, producing heat, and contain the following combustible elements: carbon, hydrogen and sulfur. A fuel must meet certain conditions, namely: to be easily obtained from nature, not to be toxic, to be inexpensive and in sufficient quantity, so that the cost of the heat obtained be competitive on the energy market. It is worth mentioning that the fuels analysed are stored ones.
The classification of fuels is done according to certain criteria, including:

a) state of aggregation - solid (coal, wood), liquid (petroleum products) and gaseous (natural gas, well gas);

b) origin - natural (wood, coal, oil, natural gas, well gas); artificial, derived from industrial processes (diesel, petrol, hydrogen, liquefied petroleum gas, biofuels) [10].

An alternative to fossil fuels is biofuels. They can be used as pure or mixed fuel with a fossil fuel. Bioethanol is mainly obtained from cereals or cane and is equivalent to petrol. Biodiesel (ethyl stearate and methyl linoleate) is mainly derived from oilseeds such as rapeseed, corn, soybeans and is similar to diesel oil.

As regards solid and liquid fuels, as well as gaseous fuels, the mass and volumetric composition, respectively the latter only in the case of gaseous ones - are expressed by specific relations [10].

For liquid petroleum fuels whose relative density, $\rho_{15}^{15}$, is known, the carbon and the hydrogen fractions can be calculated using semi-empirical relations $[10,11]$.

If a chemical formula is known for a fuel, then the mass fractions can be calculated using relations [10]:

$$
\begin{gathered}
g_{c}=\frac{12 m}{12 m+n+16 r} ; \quad g_{\mathrm{H}}=\frac{n}{12 m+n+16 r} \\
g_{\circ}=\frac{16 r}{12 m+n+16 r}
\end{gathered}
$$

For a fuel whose mass composition is known, the mass of carbon dioxide at full combustion is calculated as follows:

$$
m_{\mathrm{CO}_{2}}=\frac{g_{\mathrm{C}}}{12} \mathrm{M}_{\mathrm{CO}_{2}}
$$

In relation (2), the carbon dioxide mass has the unit of measurement $\mathrm{kg} \mathrm{CO} / \mathrm{kg}$ of fuel. For gaseous hydrocarbons whose volumetric composition is given, the volume of carbon dioxide, expressed in $\mathrm{m}^{3} \mathrm{CO}_{N} / \mathrm{m}^{3}$ of fuel resulting from full combustion, is obtained by summing up the volumes of carbon dioxide resulting from the combustion of hydrocarbons and carbon monoxide, to which the carbon dioxide that may exist in the fuel's original composition is added:

\footnotetext{
* email: cristescuteo@gmail.com
} 


$$
V_{\mathrm{CO}_{2}}=\sum\left(m r_{\mathrm{CmHn}}\right)_{i}+r_{\mathrm{CO}}+r_{\mathrm{CO}_{2}}
$$

In this case, the mass of carbon dioxide, with the unit of measurement of $\mathrm{CO}_{2} / \mathrm{m}_{\mathrm{N}}^{3}$ of fuel, is obtained as follows:

$$
m_{\mathrm{CO}_{2}}=\frac{M_{\mathrm{CO}_{2}}}{22,414} \cdot V_{\mathrm{CO}_{2}}
$$

Fuels are characterized by the heat produced by the complete combustion of the fuel quantity unit, i.e., the calorific value, with the minimum amount of air needed. There are two types of calorific value:

- superior calorific value $\mathrm{H}_{\mathrm{s}}$ - when the vapours contained in the combustion gases are discharged in liquid state - in other words, latent condensation heat is released into the combustion space;

- inferior calorific value $\mathrm{H}_{-}$- in which case the combustion gases are discharged with gaseous water vapours.

Although it is obvious that the gross calorific value is higher than the net one, often for technical reasons ( water in liquid state can be combined with some combustion gas components, forming corrosive fluids), it is recommended that combustion gases be discharged while the water they contain is in vapour state. As a result, practically, it is net calorific value that is of interest most of the times [6].

If a fuel does not contain water, the mathematical relationship between the inferior and the superior calorific value is as follows:

$$
\mathrm{H}_{i}=\mathrm{H}_{s}-2510 \cdot 9 g_{\mathrm{H}}
$$

The calorific value of a biofuel, whose chemical formula is $\mathrm{C}_{m} \mathrm{H}_{n} \mathrm{O}_{r^{\prime}}$ and which does not contain water, is calculated as follows:

$$
\mathrm{H}_{i}=33900 g_{\mathrm{C}}+120120\left(g_{\mathrm{H}}-\frac{g_{\mathrm{O}}}{8}\right)
$$

By applying relationships (5) and (6) results expressed in $\mathrm{kJ} / \mathrm{kg}$ are obtained; gare decimals.

For mixtures of gaseous fuels, the calorific value is calculated as follows [10, 11]:

$$
\mathrm{H}_{a m}=\sum_{i=1}^{n} r_{i} \mathrm{H}_{i}
$$

In the case of liquid petroleum fuels, semi-empirical relations $[10,11]$ can be used to calculate the calorific value.

The release of carbon dioxide takes place both during the combustion of fossil fuels and biofuels. In order to compare the polluting effects of fuel combustion, the carbon dioxide emission factor is used, being defined by the relation below:

$$
\varepsilon_{\mathrm{CO}_{2}}=\frac{m_{\mathrm{CO}_{2}}}{\mathrm{H}}
$$

Depending on the carbon dioxide mass/ inferior calorific value ratio, on the one hand, and the carbon dioxide mass/ superior calorific value ratio, on the other hand, the following can be distinguished:

- $\varepsilon_{\text {a }}$ carbon dioxide emission relative to the inferior calorific value;

- $\varepsilon_{\text {cors }}$ carbon dioxide emission relative to the superior calorific value for fuels whose moisture content is zero percent [6].

By using relations (1), (2), (5), (6) and (8) the following relations are suggested for the calculation of the carbon dioxide emission factor [5]:

- $\varepsilon_{\text {con }}$ carbon dioxide emission relative to the inferior calorific value $\left[\mathrm{g} \mathrm{CO}_{2} / \mathrm{kWh}\right]$ :

$$
\varepsilon_{\mathrm{CO}_{2}, I}=\frac{1000 m}{2.568 m+0.758 n-1.517 r}
$$

- $\varepsilon_{\mathrm{coz}, 1 \mathrm{~s}}$ carbon dioxide emission relative to the superior calorific value $\left[\mathrm{g} \mathrm{CO}_{2} / \mathrm{kWh}\right]$ :

$$
\varepsilon_{\mathrm{CO}_{2}, S}=\frac{1000 m}{2.568 m+0.901 n-1.517 r}
$$

In the relationships above $m, n, r$ are the coefficients of the chemical formula $\mathrm{C}_{\mathrm{H}} \mathrm{O}$.

For the calculation of the carbon dioxide emission factor, in the case of liquid petroleum fuel burning, appropriate relations have been proposed for liquid petroleum fuels that contain hydrogen and carbon only [6].

\section{Experimental part}

A large number of fuel samples in all aggregation states -gaseous, liquid and solid - were analysed.

After the chromatographic analysis reports of certain gas mixtures were analysed, five samples were considered to be representative (table 1). The composition of the gaseous samples was analysed in specialized and authorised laboratories (table 2).

According to the reports containing the results of the chromatographic analyses for gases GL1, GA1, GA2, GT1, the analyses were conducted using the VARIAN CP-3800 (fig. 1).

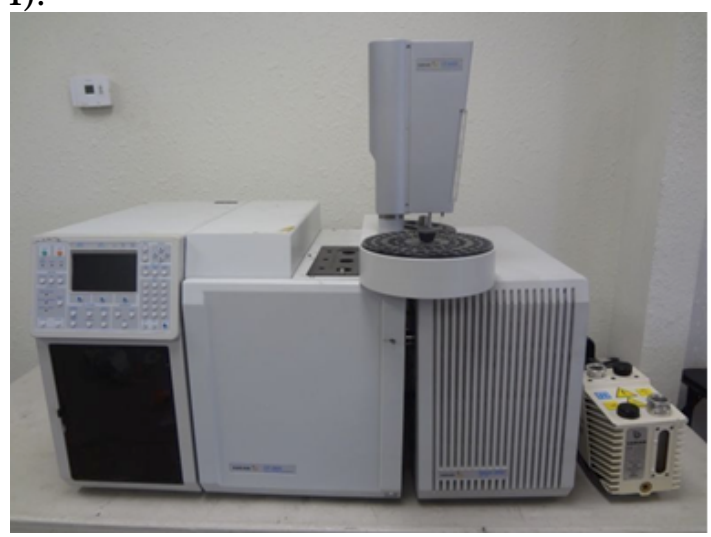

Fig. 1. Varian CP -3800 Gas Chromatograph

\begin{tabular}{|c|c|c|c|}
\hline Name of gas mixture & Symbol & Sample characterisation & Origin of analysis report \\
\hline Free gas & GL1 & $\begin{array}{c}\text { Mixture of natural gas } \\
\text { extracted from a well (free } \\
\text { gas) }\end{array}$ & $\begin{array}{c}\text { Analysis performed in } \\
\text { authorised laboratory }\end{array}$ \\
\hline Associated gas 1 & GA1 & $\begin{array}{c}\text { Oil well gas mixture } \\
\text { (associated gas) } \\
\text { Oil well gas mixture } \\
\text { (associated gas) }\end{array}$ & $\begin{array}{c}\text { Analysis performed in } \\
\text { authorised laboratory }\end{array}$ \\
\hline Associated gas 2 & GA2 & $\begin{array}{c}\text { Analysis performed in } \\
\text { authorised laboratory }\end{array}$ \\
\hline $\begin{array}{c}\text { Gases in the transportation } \\
\text { pipeline }\end{array}$ & GT1 & $\begin{array}{c}\text { Gas mixture taken from the } \\
\text { transportation pipeline } \\
\text { analysis performed in } \\
\text { authorised laboratory }\end{array}$ & $\begin{array}{c}\text { Composition taken from the } \\
\text { literature [12] }\end{array}$ \\
\hline \begin{tabular}{c} 
Shale gas \\
\hline
\end{tabular}
\end{tabular}

Table 1

NAME OF GASEOUS MIXTURES 


\begin{tabular}{|c|c|c|c|c|c|}
\hline Composition & GL1 & GA1 & GA2 & GT1 & Gsist \\
\hline & \multicolumn{5}{|c|}{ Volumetic fraction, $\%$} \\
\hline Oxygen - $\mathrm{O}_{2}$ & 0 & 0 & 0 & 0 & 2 \\
\hline Carbon Monoxide - CO & 0 & 0 & 0 & 0 & 0 \\
\hline Azote $-\mathrm{N}_{2}$ & 0.154 & 1.238 & 0.584 & 0.1242 & 0 \\
\hline Carbon dioxide - $\mathrm{CO}_{2}$ & 0.2522 & 0.669 & 1.068 & 0.3307 & 0 \\
\hline Methane - $\mathrm{CH}_{4}$ & 95.9568 & 92.018 & 93.776 & 98.3678 & 80 \\
\hline Ethan $-\mathrm{C}_{2} \mathrm{H}_{6}$ & 1.9231 & 3.105 & 2.544 & 0.7625 & 12 \\
\hline Prophan - $\mathrm{C}_{3} \mathrm{H}_{8}$ & 0.78 & 1.662 & 1.083 & 0.231 & 6 \\
\hline iso-Butane - $\mathrm{C}_{4} \mathrm{H}_{10}$ & 0.1959 & 0.294 & 0.265 & 0.0461 & 0 \\
\hline n-Butane - $\mathrm{C}_{4} \mathrm{H}_{10}$ & 0.2682 & 0.453 & 0.257 & 0.0588 & 0 \\
\hline iso-Pentane - $\mathrm{C}_{5} \mathrm{H}_{12}$ & 0.1324 & 0.172 & 0.102 & 0.0161 & 0 \\
\hline n-Pentane - $\mathrm{C}_{3} \mathrm{H}_{12}$ & 0.0882 & 0.152 & 0.059 & 0.0097 & 0 \\
\hline Hexane - $\mathrm{C}_{6} \mathrm{H}_{14}$ & 0.1115 & 0.126 & 0.081 & 0.0244 & 0 \\
\hline Heptane - $\mathrm{C}_{7} \mathrm{H}_{16}$ & 0.0935 & 0.092 & 0.05 & 0.0182 & 0 \\
\hline Octane - $\mathrm{C}_{8} \mathrm{H}_{18}$ & 0.0387 & 0.017 & 0.052 & 0.0079 & 0 \\
\hline Nonane - $\mathrm{C}_{9} \mathrm{H}_{20}$ & 0.0055 & 0.001 & 0.03 & 0.0026 & 0 \\
\hline Hydrogen sulfide $-\mathrm{H}_{2} \mathrm{~S}$ & 0 & 0.001 & 0.049 & 0 & 0 \\
\hline Total & 100 & 100 & 100 & 100 & 100 \\
\hline
\end{tabular}

Table 2

RESULTS OF THE CHROMATOGRAPHIC ANALYSIS OF GASEOUS MIXTURES

\begin{tabular}{|c|c|}
\hline Liquid fuels & $\begin{array}{c}\text { Relative density (the density of the liquid } \\
\text { fuels relative to the water, at } \mathbf{1 5}{ }^{\circ} \mathbf{C} \text { ) } \rho_{15}^{15}\end{array}$ \\
\hline Gasoline & 0.7498 \\
\hline Disel fuel & 0.8398 \\
\hline Liquefied petroleum gases & 0.5346 \\
\hline
\end{tabular}

Table 3

CHARACTERISTICS OF LIQUID FUELS

\begin{tabular}{|c|c|c|c|c|c|c|}
\hline \multicolumn{2}{|c|}{ Solid fuels } & \multicolumn{5}{|c|}{ Composition, \% } \\
\hline & & $g_{\mathrm{C}}$ & $g_{\mathrm{H}}$ & $g_{0}$ & $g_{\mathrm{N}}$ & $g_{\mathrm{S}}$ \\
\hline & Inthracite & 95.87 & 1.13 & 1.879 & 0.251 & - \\
\hline & Pit coal & 84.23 & 4.61 & 9.5 & - & 1.66 \\
\hline Lig & $\begin{array}{l}\text { te (Filipesti de } \\
\text { Pădure) }\end{array}$ & 64.9 & 5.52 & 25.79 & 1 & 2.79 \\
\hline Wood & Hardwood & 50.5 & 6.10 & 42.8 & 0.6 & - \\
\hline & Softwood & 51 & 6.15 & 42.25 & 0.6 & - \\
\hline
\end{tabular}

Table 4

CHEMICAL COMPOSITION OF SOLID FUELS

CALORIFIC VALUES OF SOLID FUELS

\begin{tabular}{|c|c|c|c|}
\hline \multicolumn{2}{|c|}{ Solid Fuels } & $\begin{array}{c}\text { Superior caloric } \\
\text { power, } \\
\mathbf{k J} / \mathbf{k g}\end{array}$ & $\begin{array}{c}\text { Inferior caloric power, } \\
\mathbf{k J} / \mathbf{k g}\end{array}$ \\
\hline \multicolumn{2}{|c|}{ Anthracite } & 24069 & 23593 \\
\hline \multicolumn{2}{|c|}{ Pit coal } & 16894 & 16371 \\
\hline \multirow{2}{*}{ Wood } & Lignite & 7552 & 6136 \\
\cline { 2 - 4 } & Hardwood & 20026 & 9258 \\
\hline
\end{tabular}

The CP-3800 GC is a gas chromatograph with a flexible platform for single, dual or three- channel configuration. The CP-3800 Gas Chromatograph allows upgrades to a multi-valve, multi-column configuration to handle complex analyses.

It is worth mentioning that after the research was conducted data regarding shale gas were collected from the literature. In Romania there is no shale gas exploitation.

The characteristics of the liquid petroleum fuels (considered representative) necessary for the calculation of the carbon dioxide emission factor are presented in table 3. They were taken from delivery certificates provided by companies that are engaged in the production or distribution of liquid petroleum products.

Table 4 contains the chemical composition of the selected solid fuels, whereas table 5 contains the gross and net calorific values, according to the literature [13].
The research carried out also included biofuels. Their names and chemical formulae are displayed in table 6.

\section{Results and discussions}

In order to assess the carbon dioxide emission resulting from the combustion of the analysed fuels relationships (8), (9) and (10) were used.

As regards gaseous fuels, the results obtained from the calculation of the carbon dioxide mass are shown in table 7.

The net and gross calorific values for samples GL1, GA1, GA2 and GT1 are taken from the chromatographic analysis reports. For shale gas these values are obtained by calculation [7], relation (7).

Table 7 shows that the calorific value of shale gas is higher than the one of the other gas mixtures. 


\begin{tabular}{|c|c|c|}
\hline Biofuel & Chemical formula & Sample characterisation \\
\hline Ethanol & $\mathrm{C}_{2} \mathrm{H}_{6} \mathrm{O}$ & $\begin{array}{c}\text { Ethanol can replace petrol or can be } \\
\text { blended with it in certain proportions; }\end{array}$ \\
\hline Ethyl stearate & $\mathrm{C}_{20} \mathrm{H}_{40} \mathrm{O}_{2}$ & $\begin{array}{c}\text { Ethyl stearate may replace - wholly or } \\
\text { partly - diesel fuel. }\end{array}$ \\
\hline Methyl linoleate & $\mathrm{C}_{19} \mathrm{H}_{34} \mathrm{O}_{2}$ & $\begin{array}{c}\text { Methyl linoleate may replace - wholly } \\
\text { or partly - diesel fuel. }\end{array}$ \\
\hline
\end{tabular}

Table 6

NAMES OF BIOFUELS

Table 7

RESULTS OF CARBON DIOXIDE MASS AND CALORIFIC VALUE CALCULATION FOR GASEOUS MIXTURES

\begin{tabular}{|c|c|c|c|c|c|}
\hline Compound & GLI & GA1 & GA2 & GT1 & Gsist \\
\hline $\begin{array}{c}\text { Carbon dioxide mass } \\
m_{\mathrm{CO}_{2},\left[\mathrm{~kg} \mathrm{CO} / \mathrm{m}^{3} \mathrm{~N} \text { comb }\right]}\end{array}$ & 2.0813 & 2.1458 & 2.0918 & 1.9946 & 2.3949 \\
\hline $\begin{array}{c}\text { Inferior caloric power, } \\
\mathrm{H}_{i}\left[\mathrm{~kJ} / \mathrm{m}^{3} \mathrm{~N} \text { comb] }\right.\end{array}$ & 35800 & 36400 & 35700 & 34400 & 41974.1 \\
\hline $\begin{array}{c}\text { Inferior caloric power, } \\
\mathrm{H}_{i}\left[\mathrm{kWh} / \mathrm{m}^{3} \mathrm{~N} \text { comb] }\right.\end{array}$ & 9.972 & 10.137 & 9.941 & 9.5567 & 11.659 \\
\hline $\begin{array}{c}\text { Superior caloric power, } \\
\mathrm{H}_{s}\left[\mathrm{~kJ} / \mathrm{m}^{3} \mathrm{~N} \text { comb] }\right.\end{array}$ & 39700 & 40400 & 39600 & 38100 & 46444.02 \\
\hline $\begin{array}{c}\text { Superior caloric power, } \\
\mathrm{H}_{s}\left[\mathrm{kWh} / \mathrm{m}^{3} \mathrm{~N} \text { comb] }\right.\end{array}$ & 11.064 & 11.226 & 11.016 & 10.608 & 12.901 \\
\hline
\end{tabular}

Table 8 contains the results obtained from the calculations for liquid fuels.

According to table 8, the calorific value of LPG is highest compared to the other liquid fuels analyzed.

As regards solid fuels, the calculation results are shown in table 9.

The results obtained from the calculation for biofuels are displayed in table 10.

Table 11 contains the carbon emission factor of the analysed fuels.
As shown in table 11, there is a decreasing distribution of fuel relative to the value of the carbon dioxide emission factor:

$$
\mathcal{E}_{\mathrm{CO}_{2}, \text { S, Solid fuel }}>\mathcal{E}_{\mathrm{CO}_{2}, \text { s, Liquid fuel }}>\mathcal{E}_{\mathrm{CO}_{2}, \text { s, Gaseous fuel }}
$$

One of the conclusions to be highlighted in table 11 is that the values of the carbon dioxide emission factor corresponding to shale gas burning are the lowest.

\begin{tabular}{|c|c|c|c|}
\hline Liquid fuels & Gasolina & Disel fuel & Liquefied petroleum gases \\
\hline Carbon mass fraction, gc & 0.8525 & 0,8659 & 0.8202 \\
\hline Hydrogen mass fraction, gH & 0.1475 & 0.1341 & 0.1798 \\
\hline $\begin{array}{c}\text { Carbon dioxide mass } m_{\mathrm{CO}_{2},} \\
{[\mathrm{~kg} \mathrm{CO} / \mathrm{kg}]}\end{array}$ & 3.126 & 3.175 & 3.007 \\
\hline $\begin{array}{c}\text { Inferior caloric power, } \\
\mathrm{H}_{i}[\mathrm{~kJ} / \mathrm{kg}]\end{array}$ & 43866.69 & 42893.94 & 45615.13 \\
\hline $\begin{array}{c}\text { Superior caloric power, } \\
\mathrm{H}_{s}[\mathrm{~kJ} / \mathrm{kg}]\end{array}$ & 47198.72 & 45921.68 & 49677.04 \\
\hline
\end{tabular}

Table 8

RESULTS OF THE CALCULATION OF LIQUID FUEL MASS FRACTION, CARBON DIOXIDE MASS AND CALORIFIC VALUE

\begin{tabular}{|l|c|c|c|c|c|}
\hline \multicolumn{1}{|c|}{ Solid fuels } & Anthracite & \multirow{2}{*}{ Pit coal } & Lignite & \multicolumn{2}{c|}{ Wood } \\
\cline { 5 - 6 } & & & & Hardwood & Softwood \\
\hline Carbon mass fraction, gc & 0.9587 & 0.8423 & 0.6490 & 0.5050 & 0.5100 \\
\hline Hydrogen mass fraction, gH & 0.0413 & 0.1577 & 0.3510 & 0.4950 & 0.4900 \\
\hline $\begin{array}{l}\text { Carbon dioxide mass, } \\
m_{\mathrm{CO}_{2}},\left[\mathrm{~kg} \mathrm{CO}_{2} / \mathrm{m}^{3} \mathrm{~N} \text { comb] }\right.\end{array}$ & 3.515 & 3.088 & 2.379 & 1.8520 & 1.8700 \\
\hline
\end{tabular}

Table 9

RESULTS OF THE

CALCULATION OF SOLID FUEL MASS FRACTION AND CARBON DIOXIDE MASS

\begin{tabular}{|l|c|c|c|}
\hline Biofuels & Ethanol & Ethyl stearate & Methyllinoleate \\
\hline Carbon mass fraction, gc & 0.5217 & 0.7692 & 0.7756 \\
\hline Hydrogen mass fraction, gH & 0.1304 & 0.1282 & 0.1156 \\
\hline Oxygen mass fraction, go & 0.3479 & 0.1026 & 0.1088 \\
\hline $\begin{array}{l}\text { Inferior caloric power, } \mathrm{H}_{i} \\
{\left[\mathrm{~kJ} / \mathrm{m}^{3} \mathrm{~N}\right]}\end{array}$ & 28125.56 & 39934.73 & 38545.1 \\
\hline $\begin{array}{l}\text { Superior caloric power, } \mathrm{H}_{s} \\
{\left[\mathrm{~kJ} / \mathrm{m}^{3} \mathrm{~N}\right]}\end{array}$ & 31071.29 & 42830.77 & 41156.50 \\
\hline $\begin{array}{l}\text { Carbone dioxide mass, } \\
m_{\mathrm{CO}_{2}},\left[\mathrm{~kg} \mathrm{CO} / \mathrm{m}^{3} \mathrm{~N} \text { comb] }\right.\end{array}$ & 1.913 & 2.82 & 2.844 \\
\hline
\end{tabular}

Table 10

CALCULATION RESULTS FOR BIOFUELS 


\begin{tabular}{|c|c|c|c|}
\hline \multicolumn{2}{|c|}{ Fuels } & $\begin{array}{l}\text { Carbon dioxide emission } \\
\text { relative to the inferior } \\
\text { caloric power } \\
{[\mathrm{g} \mathrm{CO} / \mathrm{kWh}]}\end{array}$ & $\begin{array}{l}\text { Carbon dioxide emission } \\
\text { relative to the superior } \\
\text { caloric power } \\
{[\mathrm{g} \mathrm{CO} / \mathrm{kWh}]}\end{array}$ \\
\hline \multicolumn{2}{|c|}{ Lignite } & 1396 & 1134 \\
\hline \multirow[t]{2}{*}{ Wood } & Hardwood & 720 & 330 \\
\hline & Softwood & 709 & 330 \\
\hline \multicolumn{2}{|c|}{ Pit coal } & 679 & 658 \\
\hline \multicolumn{2}{|c|}{ Anthracite } & 536 & 526 \\
\hline \multicolumn{2}{|c|}{ Methyl linoleate } & 266 & 249 \\
\hline \multicolumn{2}{|c|}{ Disel fuel } & 266 & 248 \\
\hline \multicolumn{2}{|c|}{ Gasoline } & 257 & 238 \\
\hline \multicolumn{2}{|c|}{ Ethyl stearate } & 254 & 237 \\
\hline \multicolumn{2}{|c|}{ Ethanol } & 245 & 222 \\
\hline \multicolumn{2}{|c|}{ Liquefied petroleum gases } & 237 & 218 \\
\hline \multicolumn{2}{|c|}{ GA1 } & 211 & 191 \\
\hline \multicolumn{2}{|c|}{ GA2 } & 210 & 190 \\
\hline \multicolumn{2}{|c|}{ GL1 } & 209 & 188 \\
\hline \multicolumn{2}{|c|}{ GT1 } & 209 & 188 \\
\hline \multicolumn{2}{|c|}{ Gsist } & 205 & 186 \\
\hline
\end{tabular}

Table 11

CARBON EMISSION FACTOR OF ANALYSED FUELS
It is seen that, for lignite, the carbon dioxide emission relative to the net calorific value is the highest, $\varepsilon_{\mathrm{CO2, \text {,Lignite }}}=$ $1396 \mathrm{~g} \mathrm{CO}_{2} / \mathrm{kWh}$., whereas shale gas has the lowest value, $\varepsilon_{\text {COZ, S, Gsist }}=205 \mathrm{~g} \mathrm{CO}_{2} / \mathrm{kWh}$.

As' regards the carbon dioxide emission relative to the gross calorific value, table 11 shows that lignite has the highest value, $\varepsilon_{\mathrm{CO}, \text { S, Lignite }}=1136 \mathrm{gCO}_{2} / \mathrm{kWh}$, whereas shale gas has the lowest value, $\varepsilon_{\text {cors.Gsist }}=186 \mathrm{~g} \mathrm{CO}_{2} / \mathrm{kWh}$.

The highest values of the carbon dioxide emission factor are obtained for solid fuels, namely:

$$
\begin{gathered}
\mathcal{E}_{\mathrm{CO}_{2}, \text { S, Lignite }}>\mathcal{E}_{\mathrm{CO}_{2}, \text { S, Hardwood }}>\mathcal{E}_{\mathrm{CO}_{2}, \text { S, Softwood }}> \\
>\mathcal{E}_{\mathrm{CO}_{2}, \text { S, Coal }}>\mathcal{E}_{\mathrm{CO}_{2}, \text { S, Anthracite }}
\end{gathered}
$$

As for biofuels, table 11 shows that:

$$
\varepsilon_{\mathrm{CO}_{2}, I, \text { Metiyl linoieate }}>\varepsilon_{\mathrm{CO}_{2}, I, \text { Etwyl stearate }}>\varepsilon_{\mathrm{CO}_{2}, I, \text { Etanol }}
$$

As shown in table 11, petrol and ethanol blending leads to the reduction of carbon dioxide emissions.

The new European Directives require that starting 1 January 2018 Romania should introduce on the market petrol with a biofuel content of at least $8 \%$ by volume. As of 1 J anuary 2016, diesel fuel must have a biofuel content of at least $6.5 \%$ by volume. Biofuels are fuels produced from renewable resources, and their use reduces carbon dioxide emissions [14].

According to the National Institute of Statistics, in 2016 biofuel consumption in transport increased by $4.46 \%$ compared to the year 2000.

According to the data provided by S.C. Enel Energie Muntenia S.A., the $\mathrm{CO}_{2}$ emission factor in Romania for the year 2016 was $287.11^{2} \mathrm{~g} / \mathrm{kWh}$.

\section{Conclusions}

From a qualitative point of view, the evaluation of the carbon dioxide emission factor provides a hierarchy of the main fuels used.
From a quantitative point of view, the amount of carbon dioxide that reaches the atmosphere can be estimated for each fuel type.

Depending on the amount of carbon dioxide released by combustion, a strategy for each fuel category/type can be created.

The carbon dioxide emission factor can be used as an additional criterion for making decisions regarding fuel choice and energy strategy.

\section{Nomenclature}

$g_{i}$ - Mass fraction of component $i$ in a gas mixture, $\mathrm{kg}$ component $i / \mathrm{kg}$ fuel;

$\mathrm{H}$ - Caloric Power, $\mathrm{kJ} / \mathrm{kg}, \mathrm{kJ} / \mathrm{m}^{3}{ }_{\mathrm{N}}$;

$M$ - Molar Mass, kg/kmol;

$\mathrm{m}$ - Mass, kg;

$r_{i}$ - Volumetric fraction of component $i$ in a gas mixture, $m_{N}^{3}$ component $i / m^{3}$ fuel;

V-Volume, $\mathrm{m}^{3}$

$\varepsilon_{\mathrm{CO}^{-}}$- Carbon dioxide emission, $\mathrm{g} / \mathrm{kWh}$;

$\rho_{15}$-Relative density (the density of the liquid petroleum fuels relative to the water, at $15^{\circ}$ )

\section{Subscript}

C - Carbon

$\mathrm{CO}_{2}$ - carbon dioxide

$\mathrm{H}$ - Hydrogen

I - Inferior

$m$ - coefficient

$n$ - coefficient

0 - Oxygen

$r$ - coefficient

$S$ - Superior

\section{References}

1.***http://www.minind.ro/dezbateri_publice/2011/strategia_ energetica_20112035_20042011.pdf

2. *** Anexa 1 la Hotararea Guvernului nr. 739/2016-Strategia naionala privind schimbarile climatice si cresterea economica bazata pe emisii reduse

3. *** https://www.green-report.ro/emisii-de-co2-au-scazut-romania 
4. AVRAM, L., CRISTESCU, T., STOICA, M.E., Carbon Dioxide Emissions Monitoring in Romania in the Context of Greenhouse Gases Reduction, The first International Conference on Energy, Power, Petroleum and Petrochemical Engineering, Lebanese University, Beirut, Lebanon, April 26-28, 2017, p.104-106, IEEE.

5. CRISTESCU, T., STOICA, M.,E., Evaluation of the Emission of Carbon Dioxide in the Combustion of Biofuels and Comparison with Liquid Petroleum Products, Indian J ournal of Applied Researche, vol 3, Issue 10, October, 2013, pg. 28-30.

6. CRISTESCU, T., STOICA, M.-E., BRANOIU, GH., NEGREANU-PIRJOL, T., Evaluation and Comparing of the Carbon Dioxide Emission Coefficients for the Combustion of Gaseous and Liquid Hydrocarbons, Rev. Chim (Bucharest), 65, no.7, 2014, p.856-860.

7. RAZNJEVIC, K., Tabele si diagrame termodinamice, Editura Tehnica, Bucuresti, 1978, p. 327.

8. ***www.insse.ro
9. AVRAM, L., CRISTESCU, T., STOICA, M, Energy ManagementStrategies in the Oil Industry for Chemical and Thermal Environment Pollution Reduction, MATEC Web Conf. Volume 121, 2017, 8th International Conference on Manufacturing Science and Education - MSE 2017 Trends in New Industrial Revolution, https://doi.org/10.1051/matecconf/ 201712109001.

10. CRISTESCU,T., Termotehnica, Ed. University of Ploiesti, Ploie-0ti, 2009, p. 145.

11. CERNEA, A.,R., DOBRINESCU, D., FAGARASANU, I., COVACI, A., Termotehnica, Editura Diactica si Pedagogica, Bucuresti, 1969, p. 273. 12. DAOLUN LI, LONGJUN ZHANG, JOHN YILIN WANG, DETANG LU, Composition - Transient Analysis in Shale - Gas Reservoirs With Consideration of Multicomponent Adsorption, SPE Journal, Aprilie 2016, p. 648-664

13. MARINESCU, M., STEFANESCU D., CHISACOF, AL., ADLER, O., Instalatii de ardere - culegere de probleme pentru ingineri, Editura Tehnica, Bucuresti, 1985

14. ${ }^{* * *}$ http://www.economica.net

Manuscript received: 19.06 .2018 